\title{
THE INFLUENCE OF DRIVING LICENSE REGISTRATION QUALITY SERVICE TOWARDS APLICANT SATISFACTION IN SATPAS RESORT POLICE OF NGANJUK
}

\author{
Lebang Christopher Adikara \\ Postgraduate School, Airlangga University, Indonesia \\ E-mail: lebang106@yahoo.com
}

\begin{abstract}
In this democracy era, people are start be brave to deliver their opinion and aspiration, they also start to criticise the government. They demand for their right and ask for improvement for the need that the government failed to provide. The aspiration from society is very important for Indonesian police; the aspiration will improve and change any policy that does not meet the requirement from society. One of department which always become major interest is the driving license service. In order to improve the service to society, Quick Win is one of Polri program to gain trust and interest among people.
\end{abstract}

\section{KEY WORDS}

Quality, service, driving, license applicant, satisfaction.

In this democracy era, people are start be brave to deliver their opinion and aspiration, they also start to criticise the government. They demand for their right and ask for improvement for the need that the government failed to provide. The aspiration from society is very important for Indonesian police, the aspiration will improve and change any policy that does not meet the requirement from society. One of department which always become major interest is the driving license service. This department often badly reviewed by society as it is one of the most important department among people. Driving license is one of state license, published by Polri, its function is to inform that the owner is able to drive their motor vehicle.

Such condition will, of course, influence the quality service parameters by society. It will break the name of institution of Polri as failed to provide satisfaction for applicants of driving license. The public trust parameters of society towards Polri will be declined by this phenomenon, the accountability performance of Polri will be also influenced. Moreover, there will be many people who lack of driving ability but possessed a driving license which will result in increasing number of accidents in high way. There are many accidents caused by the driver who lack of ability to control their driving skill. This is very dangerous as it could threaten the life of the driver an other people in the road.

In order to regain the public trust, Polri has developed a program called Quick Wins. It is one of Polri program to gain trust and interest among people. "the trust issues from society for working performance of Polri is common problem for decades, Polri has been worked to improve and fix this uncomfortable environment.

Quick wins is the implementation and realisation of Ministry of State Appartus Empowerment regulation number Kep: 26/Menpan/2004 which has vision to improve the quality service of Polri. The improvement of driving license registration service, as stated in Quick Wins, it must follow the concept of quick, appropriate, simple, and inexpensive. The quick concept means that the quality must be well planned and well controlled, appropriate means effectiveness of the service, simple means that the bureaucracy must not contain unnecessary steps, and inexpensive means the cost for registration must not become big burden of society economy condition.

\section{METHODS OF RESEARCH}

Quantitative approach is used for this study. Yin (2011: 235) stated that quantitative approach is a strategy to collect data and provided them in numbers and statistic. The method used in this study is survey. Jackson (2009: 16) states that survey method is an act 
of giving questions or topics to individuals and explain their responses. Survey could be determined by phone, letter, and internet. Or face to face interview. One of advantage by using survey than descriptive is that the researcher is allowed to make an experiment easier in larger scale.

\section{RESULTS AND DISCUSSION}

After meeting the requirement of classic assumption test, the regression model used in this study is already appropriate. It will be used to test the influence of quality service towards customer satisfaction. The table below uses the result of analysed regression data in SPSS 2.0 version. The result could be seen in the table below.

Table 1 - Simplified Linier Regression Test

Summary ${ }^{\mathrm{b}}$ Model

\begin{tabular}{|c|c|c|c|c|}
\hline Model & $\mathrm{R}$ & $\mathrm{R}$ Square & Adjusted R Square & Std. Error of the Estimate \\
\hline 1 &, $502^{\mathrm{a}}$ &, 252 &, 246 & 6,071 \\
\hline
\end{tabular}

a. Predictors: (Constant), $X$

b. Dependent Variable: $Y$

According to the table result above, it could be concluded that coefficient correlation result between quality service and customer satisfaction is 0,502 . Meanwhile, the value of coefficient determination ( $R$ square) is 0,252 . We could synthesis the quality service influence towards customer satisfaction is about $25,2 \%$. The next step is to measure the amount of significance level of the influence. In order to obtain that, the t-test is applied which is measured by SPSS 2.0 version. The result will be as follow:

Table 2 - Significance Test Result

Coefficients $^{a}$

\begin{tabular}{|c|c|c|c|c|c|}
\hline \multirow{2}{*}{ Model } & \multicolumn{2}{|c|}{ Unstandardized Coefficients } & \multirow{2}{*}{$\begin{array}{c}\text { Standardized Coefficients } \\
\text { Beta }\end{array}$} & \multirow{2}{*}{$t$} & \multirow{2}{*}{ Sig. } \\
\hline & $\mathrm{B}$ & Std. Error & & & \\
\hline $\begin{array}{cc} & \text { (Constant) } \\
\mathrm{X} 1\end{array}$ & $\begin{array}{c}62,481 \\
, 344\end{array}$ & $\begin{array}{c}7,319 \\
, 055\end{array}$ & ,502 & $\begin{array}{l}8,537 \\
6,307\end{array}$ & $\begin{array}{l}, 000 \\
, 000\end{array}$ \\
\hline
\end{tabular}

a. Dependent Variable: $Y$

Based on the significance test results, it can be explained that the $t$ test results, the $t_{\text {count }}=6.307$ with Sig $=0,000$. While $t_{\text {table }}$ value $(0,05,118)=1,9802$. It can be synthesized that service quality variables positively affect customer satisfaction, with alpha significance value smaller than 0.05 (viewed from two directions). While the hypothesis used in testing one direction (positive or negative side) can be used column 5 (five) with the test sequence as follows:

1. The formula of Hypothesis will be as follow:

$\mathrm{H} 01$ : The quality service $(\mathrm{X} 1)$ does not influence customer satisfaction (Y)

$\mathrm{H} 11$ : There is influence of quality service $(\mathrm{X} 1)$ towards customer satisfaction $(\mathrm{Y})$

2. The significance level used in this study is using alpha level which is $(\alpha)=5 \%$..

3. As known $t_{\text {count }}$ (is obtained by dividing regression coefficient in $2^{\text {nd }}$ column within error standard in $3^{\text {rd }}$ column) table 5.20 , according to the order of $X$ variable, the variable of $t_{\text {count }}$ value is 6,307 .

4. As known $t_{\text {table }}$ is within alpha $(\alpha)=5 \%$. Because, the object of study is only one way whether it is positive only or negative only. That is why, the alpha value is divided by two, it becomes 0,025 within $n-k=120-2=118$ degree of freedom/df ( $n$ represent the amount of samples while $k$ is the amount of variable in $X$ and $Y$ ). Thus, the $t_{\text {table }}$ value is 1,9802 (Tabel t, Deny Kurniawan, 2008:7). 
5. The criteria of this experiment test will be as follow:

$H_{0 i}$ is positive and $H_{1}$ is negative if $-t_{\text {table }} \leq t_{\text {count }} \leq t_{\text {table }}$ within the decision is that there is no influence of quality service toward customer satisfaction.

$H_{0 i}$ is negative and $H_{1}$ is positive if $t_{\text {count }}>t_{\text {table }}$ or $-t_{\text {count }}<-t_{\text {table, }}$, within decision that quality service influence customer satisfaction.

6. As the value of tcount is $6,307>$ ttable $=1,9802$ and the value of Sigcount $=(0,000)<$ Sig table $(0,05)$, it means that $\mathrm{HO}$ is rejected while $\mathrm{H} 1$ is accepted. It could be synthesised that there is significant influence of quality service towards customer satisfaction.

7. In conclusion, because value of tcount $>$ ttable, it sums up that there is influence of quality service $(\mathrm{X})$ towards customer satisfaction $(\mathrm{Y})$. Whereas, the variable of quality service gives positive impact to customer satisfaction.

After $\mathrm{t}$ test, the next step is to testify linier regression model for influence of customer service as follow:

Table 3 - Linier Regression Table

Coefficients $^{a}$

\begin{tabular}{|c|c|c|c|c|c|}
\hline \multirow{2}{*}{ Model } & \multicolumn{2}{|c|}{ Unstandardized Coefficients } & Standardized Coefficients & \multirow{2}{*}{$t$} & \multirow{2}{*}{ Sig. } \\
\hline & $B$ & Std. Error & Beta & & \\
\hline $1 \begin{array}{c}\text { (Constant) } \\
\mathrm{X} 1\end{array}$ & $\begin{array}{c}62,481 \\
, 344\end{array}$ & $\begin{array}{l}7,319 \\
, 055\end{array}$ & ,502 & $\begin{array}{l}8,537 \\
6,307\end{array}$ & $\begin{array}{l}, 000 \\
, 000\end{array}$ \\
\hline
\end{tabular}

a. Dependent Variable: $Y$

The table above explains the linier regression table model of quality service toward customer satisfaction, as follow:

$$
\begin{gathered}
\hat{Y}=a+b_{1} X_{1} \\
\hat{Y}=66,481+0,344 X_{1}
\end{gathered}
$$

Where:

- a: 66,481 , if quality service value is zero, it means that the average customer satisfaction value (the value of quality service is constant, as the result of major perception of society to police) possessed 66,481 points.

- $b_{1}=0,344$, it means that the regression coefficient value of quality service $(X)$ is 0,344 . It states for every 1 point increasing quality service, it will increase the average point of customer satisfaction point for 0,344 .

- In general, from the test above, it could be concluded that the quality of service influence the customer satisfaction positively. In order to measure the accuracy of the variables' linier, there will be a screenshot of SPSS 2.0 version output about the accuracy of each variable.

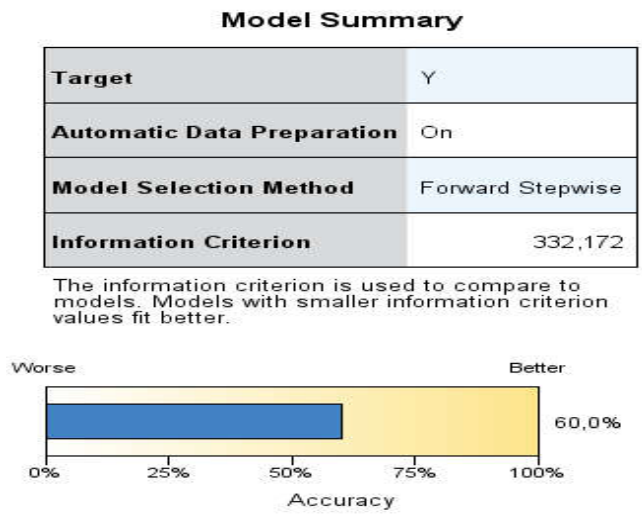

Figure 1 - Linearity Level Figure 
From the figure above, it could be seen that the regression linearity level is $60 \%$ which includes in good category. In general, we could assume that the quality of driving license registration service, generally, has positive value towards society satisfaction as license applicant in Satpas Nganjuk Police.

\section{DISCUSSION OF RESULTS}

The hypothesis which states that there is an influence of quality service towards customer satisfaction. It is supported by coefficient correlation (R) between quality service and customer satisfaction is 0,502 . Meanwhile, the value of determination coefficient $(R$ square) is 0,502 . It could be synthesised that the influence of quality service towards customer satisfaction is $25,2 \%$.

After the value of quality service influence towards customer satisfaction, the next step is to measure the amount of significance level of the influence. In order to obtain that, the ttest is applied which is measured by SPSS 2.0 version. it can be explained that the $t$ test results, the $t_{\text {count }}=6.307$ with Sig $=0,000$. While $t_{\text {table }}$ value $(0,05,118)=1,9802$. The criteria of the test are as follow:

- $\mathrm{H}_{0 \mathrm{i}}$ is positive and $\mathrm{H}_{1}$ is negative if $-\mathrm{t}_{\text {table }} \leq \mathrm{t}_{\text {count }} \leq \mathrm{t}_{\text {table }}$ within the decision is that there is no influence of quality service toward customer satisfaction.

- $\mathrm{H}_{0 \mathrm{i}}$ is negative and $\mathrm{H}_{1}$ is positive if $\mathrm{t}_{\text {count }}>\mathrm{t}_{\text {table }}$ or $-\mathrm{t}_{\text {count }}<-\mathrm{t}_{\text {table, }}$ within decision that quality service influence customer satisfaction.

As the value of tcount is $6,307>$ ttable $=1,9802$ and the value of Sigcount $=(0,000)<$ Sig table $(0,05)$, it means that $\mathrm{HO}$ is rejected while $\mathrm{H} 1$ is accepted. It could be synthesised that significant influence of quality service towards customer satisfaction is around $\alpha=0,05$. The influence is also showed by the simplified regression linier model which stated below:

a. if quality service value is zero, it means that the average customer satisfaction value possessed 66,481 points.

b. It means that the regression coefficient value of quality service $(X)$ is 0,344 . It states for every 1 point increasing quality service, it will increase the average point of customer satisfaction point for 0,344 .

Generally, from the linearity model above, it could be predicted that quality service give positive influence towards customer satisfaction. The finding of this study shows that the society as applicants of driving license registration assume that the quality service of the license is high within average score $86,55 \%$. Thus, it could be concluded that the quality service provided by Police of Nganjuk is already in excellent service.

According to questionnaire score, the total quality service variable value is 18600 . Meanwhile, the amount of total questionnaire $(X)$ is 16069 . The continuum category measure the high score as 13640,50 , medium is 8680,50 , and the low score is 3720,50 . Thus, the variable standing position of quality service continuum is as follow:

- The low continuum range, 3720,50 - 8680;

- The medium continuum range, 8680,50 - 13640;

- The high continuum range, $13640,50-18600$.

It means that the total continuum range which is 16069 isplaced on high continuum category which range between 13640,50 - 18600. Meanwhile, the total customer satisfaction variable value 15000 , from the questionnaire table, the value of $(Y)$ is 13021 . The continuum category divides the high score category ranges 11000,50 , the medium is 7000,50 , while the low point is 3000,50 . Thus, the descending position for customer satisfaction towards driving license registration will be as follow:

- The low continuum range, 3000,50 - 7000;

- The medium continuum range, $7000,50-11000$;

- The high continuum range, 11000,50 - 15000 .

The value of customer satisfaction in this study, which is 13021, is included in high category within 11000,50 - 15000 scores. Based on the finding, it could be concluded that the better quality service the better customer satisfaction. This could be shown by the value 
of each variable which possessed percentage of $86,55 \%$ from the responds of every sample while the percentage of customer satisfaction is around $86,70 \%$.

Goesth and Davis cited Tjiptono (2004: 51), argued that quality is defined "as a dynamic condition in which it deals with products, services, people, processes and environments that meet or exceed expectations. While Christopher Lovelock and Lauren Wright (2008: 14) state that "quality: the degree to which a customer satisfies service by meeting their needs, wants and expectations.". In accordance with the statements above, theory of Heskett cited by Proctor (2000: 279) states that; the relationship between the quality of internal services and the quality of external services which furthermore relate to customer satisfaction, customer loyalty and organizational profitability. They propose that high quality internal services lead to increased employee satisfaction which in turn leads to increased service value and increased external customer satisfaction.

The existence of Nganjuk SATPAS, in serving the duty to society, must meet the expectation of society in diversity. The society which comes from elements of varieties, they must obtain service which is equal, predictable, expected, and tolerant zone between quality service and applicant satisfaction. If the conditions above are fulfilled, there will be feelings of secured, security, ordinance, peaceful, to support the productivity of society.

Yogi S \& M. Ikhsan (2006: 279) states that public service is close to bureaucracy government representation, because it is a direct function of government to serve its people. That is why, the quality service of an institution is the reflection its bureaucracy. In conclusion, this must be the fundamental procedure for the state to serve the people, this must also be followed by Nganjuk Police Officers.

According to the regulation of Ministry of State Apparatus Empowerment (Meneg PAN) number 63/KEP/M.PAN/7/2003 educates people that public service is an act of effort to service the society done by the state apparatus as the realisation of people needs or the implementation of constitution law.

Moreover, in Law article 13 number 12 of 2002 about the Police of Indonesian Republic, it states that: the fundamental duty of police is to: maintain the security and the orderliness of society; law empowerment, and; give protection, aegis, and service to society.

According to the decision of Menag PAN and the Law formulation above, the general duty of police is to serve the society. Thus, for SATPAS Nganjuk Police department, to serve and give best quality service to people is mandatory. It is important to give the best service as it will increase the image of Police among society. Starting from this understanding, the police officers of Nganjuk try to give their best service to the smallest element of society universally whereas they are the judger of law and protector of its people.

There are many strategic, innovative, and creative ways provided by Nganjuk Police as the reformation movement in every department, driving license registration becomes one of focus. Unfortunately, there is no such an easy way to reform all of it in instant time, by planning a good, fixed, and consistent bureaucracy will produce more actual, aspirative, and accommodative policies. That is why, bureaucracy reformation will demand Police of Nganjuk to keep correcting their policies internally as the people satisfaction will always be maintained and improved.

\section{CONCLUSION AND SUGGESTIONS}

According to the finding and discussion of the study, it concludes that there is a direct positive influence of quality service toward customer satisfaction as the applicants of driving license registration. In other words, Tangibles, Reliability, Responsiveness, Competence, Courtesy, Credibility, Security, Access, Communication, and Understanding the customer contributes $25,2 \%$ simultaneously towards customer satisfaction variable which are the applicants of driving license.

There are several suggestions by the researchers as follow:

- There must be consolidation of communication indicator from the officers to improve the customer satisfaction as it possesses the lowest point. 
- The responds to people needs must a little bit faster. A fast and accurate service of an institution become major focus in serving people to obtain driving license, the process must be in time to wipe out a bad or negative perceptions of the applicants to the procedure and the officers.

- There should total quality service to maintain prime performance.

- The leader of institution should be a good model to represent a positive cultures among the officers.

- Another study to examine another variable is a good option such as organization environment, working ethos, discipline work and other variables which has connection with customer satisfaction.

\section{REFERENCES}

1. Republik Indonesia. 2002. Undang-Undang No. 2 tahun 2002 tentang Kepolisian Negara Republik Indonesia.

2. Republik Indonesia. 2009. Undang-Undang Nomor 22 tahun 2009 tentang Lalu Lintas and Angkutan Jalan Raya

3. Republik Indonesia. 2009. Undang-Undang Nomor 25 tahun 2009 tentang Pelayanan Publik

4. Peraturan Pemerintah No 44 tahun 1993

5. Peraturan Pemerintah No 96 Tahun 2012

6. Kep Menpan No. Kep: 26/Menpan/02/2004

7. Keputusan Menteri Negara Pendayagunaan Aparatur Negara (Meneg PAN) Nomor 63/KEP/M.PAN/7/2003

8. Kebijakan Kapolri tentang Grand Strategy polri $2005-2025$

9. Kebijakan Kapolri tentang PROMOTER (Profesional, Modern and Terpercaya)

10. Perkap No. 23 tahun 2010 tentang Polres/Polsek

11. Perkap No. 9 tahun 2012 tentang Surat ljin Mengemudi (SIM)

12. Kebijakan Kapolda Jawa Timur tentang PATUH (Proaktif, Amanah, Tegas, Unggul and Humanis) sebagai tindak lanjut untuk pencapaian dari program PROMOTER

13. Ahmad, F. S., Ihtiyar, A., \& Omar, R. 2014. A Comparative Study On Service Quality In The Grocery Retailing: Evidence From Malaysia And Turkey. Procedia- Social and Behavioral Sciences, 109, 763-767.

14. Amin, M., Yahya, Z., Ismayatim, W. F. A., Nasharuddin, S. Z., \& Kassim, E. 2013. Service Quality Dimension And Customer Satisfaction: An Empirical Study In The Malaysian Hotel Industry. Services Marketing Quarterly, 34(2), 115-125.

15. Anthony, Robert N., Vijay Govindarajan. 1995. Management Control Systems. Eight edition. Boston:Richard D. Irwin, Inc. 54

16. Ardianto, Elvinaro. 2010. Metodologi Penelitian untuk Public Relations: Kuantitatif and Kualitatif. Bandung: Simbiosa Rekatama Media .47

17. Ariani. Dorothea Wahyu. 2008. Manajemen Kualitas Pendekatan Sisi Kualitatif, Jakarta, Ghalia Indonesia. 8

18. Birowo, M. Antonius. 2004. Metode Penelitian Komunikasi: Teori and Aplikasi. Yogyakarta: Gitanyali

19. Bramesti, Getut. 2008. Kupas Tuntas Data Penelitian Dengan Spss 22. Jakarta: PT. Elex Media Komputindo. 2008. 75

20. Brown, Stanley A. 1992. Total Quality Service. Ontario: Prentice Hall Inc. 9

21. Burke, Ronald J. 2004. Journal of Organizational Change Management; Workaholism in Organizations: Work and Health Consequences. Vol 17 No 5. Emerald Group Publishing Limited. 430

22. Canarslan, N.O., 2013. A Comparison of Customers Responses to E-Service Quality Statements: Customer Encountered vs. Not Encountered Problems. International Journal of Business and Social Science, 4(11) pp.312-318. 
23. Chinomona, R., Masinge, G, and Sandada, M. 2014. The influence of E-service quality on Customer Perceived Value, Customer Satisfaction and Loyalty in South Africa. Mediterranean Journal of Social Sciences, .5(9), pp. 331-341.

24. Creswell, John W. 2013. Research Design: Pendekatan Kualitatif, Kuantitatif, and Mixed. Yogyakarta: Pustaka Pelajar

25. Dahlgaard, Jens J., Kai Kristensen and Gopal K. Kanji. 2007. Fundamentals of Total Quality Management: Process Analysis and Improvement. London: Taylor \& Francis eLibrary. 264 - 295

26. Den Hartog, Deanne N., and Robert M. Verburg. 2002. Service Excellence From the Employees' Point of View: The Role of First Line Supervisors. Managing Service Quality. Volume 12. Number 3. 162

27. Ford, John., et.al. 2016. Cultural Influences On Expectations And Evaluations Of Service Quality In Emerging Markets. International Marketing Review 33:1, 88-111.

28. Gaspersz, Vincent. 2001. Total Quality Management. Jakarta: Gramedia. 5-64

29. George, A., \& Kumar, G. S. G. 2014. Impact Of Service Quality Dimensions In Internet Banking On Customer Satisfaction. Decision, 14(1), 73-85.

30. Ghozali, Imam. 2001. Statistik Parametrik: Teori and Aplikasi dengan SPSS. 56 -96

31. Girardi, Antonia. 2009. "Pengaruh Mediasi Pemberdayaan dalam Hubungan antara Kepemimpinan Transformasional and Kualitas Layanan. Jurnal. Murdoch Business School, Murdoch University.

32. Hardiyansyah. 2011. Kualitas Pelayanan Publik: Konsep, Dimensi, Indikator and Implementasinya. Yogyakarta: Penerbit Gava Media

33. Heller. Frank \& Antonio Ruiz_Quintanilla. 1995. The Work Ethic. New York: Cornell University. 95

34. Hermansyah. 2002. Analisis Hubungan Pelayanan and Kinerja Pegawai Terhadap Citra Organisasi "Samsat". Tesis. Jakarta: Universitas Indonesia

35. Heskett, James L. 2002. Beyond Customer Loyalty. Managing Service Quality an International Journal. Volume 12. Number 6. ISSN 0960-4529. 355

36. Ivanauskienè, Neringa., \& Justina Volungènaitè. 2014. Relations Between Service Quality And Customer Loyalty: An Empirical Investigation Of Retail Chain Stores In Emerging Markets. American International Journal of Social Science, Vol. 3 No. 2

37. Keiningham, Timothy L. et.al. 2005. Does Customer Satisfaction Lead to Profitability?. Managing Service Quality an International Journal. Volume 15, Number 2. ISSN 09604529. 172

38. Kelana, Momo. 2008. Undang - Undang No. 2 Tahun 2002 tentang Undang-Undang Kepolisian Negara Republik Indonesia, Jakarta: PTIK Press.

39. Kitapci, O., Dortyol, I. T., Yaman, Z., \& Gulmez, M. 2013. The Paths From Service Quality Dimensions To Customer Loyalty: An Application On Supermarket Customers. Management Research Review, 36(3), 239-255.

40. Kitapci, O. et.al. 2014. The Impact of Service Quality Dimensions on Patient Satisfaction, Repurchase Intentions and Word-of-Mouth Communication in the Public Healthcare Industry. Elsevier Ltd. Procedia - Social and Behavioral Sciences 148. 161 - 169

41. Khan, Kaleem Mohammed., and Mohammed Naved Khan. 2008. The Encyclopaedic Dictionary of Marketing. 443 - 495

42. Khan, M. and Fasih, M. (2014). Impact of Service Quality on Customer Satisfaction and Customer Loyalty: Evidence from Banking Sector. Pakistan Journal of Commerce and Social Sciences, [online] 8(2), pp.331- 354.

43. Kotler, Philip. \& Kevin Lane Keller. 2006. Marketing Management. $12^{\text {th }}$ ed. New Jersey: Pearson Education, Inc. 372

44. Kotler, Philip., and Gary Amstrong, 1996, Dasar-Dasar Pemasaran, Edisi V, jilid 2, Intermedia, Jakarta. 661

45. Kuncoro, Mudrajad. 2011. Metode Kuantitatif: Teori and Aplikasi untuk Bisnis and Ekonomi. Yogyakarta: UPP STIM YKPN. 125 
46. Kurniasari, Ardiana., and Cholichul Hadi. 2012. "Penilaian Kualitas Pelayanan Jasa oleh Konsumen Bengkel Resmi Sepeda Motor Honda AHASS UD. Ramayana Motor Surabaya." Jurnal. Fakultas Psikologi Universitas Airlangga.

47. Langton, Nancy., and Stephen P. Robbins. 2009. Fundamental of Organizational Behavior. Third canadian edition. Vancouver: John Wiley \& Sons, Inc. 86

48. Lovelock, Christopher., and Lauren Wright. 2008. Principles of Service Marketing and Management. $6-14$

49. Lupiyoadi, Rambat, and A. Hamdani. 2006. Manajemen Pemasaran Jasa. Edisi 2. Jakarta: Salemba Empat

50. Mahfooz, Yasser. 2014. Relationship between Service Quality and Customer Satisfaction in Hypermarkets of Saudi Arabia. International Journal of Marketing Studies; Vol. 6, No. 4.

51. Markovic, S., \& Raspor, S. 2010. Measuring Perceived Service Quality Using SERVQUAL: A Case Study Of The Croatian Hotel Industry. Management, 5 (3), 195-209.

52. Mathis, Robert L., and John H. Jackson. 2008. Human Resource Management, $12^{\text {th }}$ Edition. Mason: Thomson South-Western.

53. Messner, Wolfgang. 2016. The Impact Of An Aircraft's Service Environment On Perceptions Of In-Flight Food Quality. Journal of Air Transport Management, 123-130.

54. Muhammad, Farouk and Djaali. 2003. Metodologi Penelitian Sosial, Jakarta: PTIK Press. $65-73$

55. Muhammad, Farouk, dkk, 2006. Metodologi Penelitian, Modul A2536/ 2SKS, Jakarta: PTIK. 124

56. Muhammad, Farouk. 2005. Menuju Reformasi Polri, Jakarta, Restu Agung bekerjasama dengan PTIK Press

57. Naidu, N.V.R., K.M. Babu, and Sri G. Rajendra. 2006. Total Quality Management. New Delhi: New Age International (P) Ltd. 43 - 44

58. Nasution, M.N. 2005. Manajemen Kualitas Terpadu. Bogor: Ghalia Indonesia. 3

59. Ohei, Nona Pricillia. Pengaruh Kualitas Pelayanan Penyidikan Anggota Satuan Indag Ditreskrimsus Polda Metro Jaya Terhadap Kepuasan Korban Tindak Pidana Merek. Skripsi. Jakarta: PTIK

60. Omachonu, Vincent K. \& Joel E. Ross. 2005. Principles of Total Quality. Florida: Taylor \& Francis e-Library. 472

61. Paisal, Sanapiah. 1981. Dasar and Teknik Menyusun Angket. Surabaya: Usaha Nasional. 2-3

62. Parasuraman, A. 2008. A Conceptual Model Of Service Quality And Its Implication For Future Research. Jounal of marketing. 27

63. Prayudha, A. and Harsanto, B. 2014. Measuring Service Quality In Hotel X Bandung. International Symposium on Technology Management and Emerging Technologies

64. Proctor, Tony. 2000. Strategic Marketing: An Introduction. London:Routledge. 47

65. Purwanto, A Erwan and Dyah R Sulistyastuti. 2007. Metode Penelitian Kuantitatif Untuk Administrasi Publik and Masalah - Masalah Sosial Yogyakarta: Gava Media. 198-200

66. Rakhmat, Jalauddin. 1999. Metode Penelitian komunikasi. Bandung: PT. Remaja Rosdakarya.83

67. Rivai, Veithzal. 2003. Manajemen Sumber Daya Manusia untuk Perusahaan: Dari. Teori ke Praktik. Jakarta: PT.Rajagrafindo Persada. 14

68. Rivard, Suzanne. 2004. Information Technology and Organizational Transformation Solving the Management Puzzle. Burlington: Elsevier Butterworth-Heinemann. 94

69. Robbins, Stephen P., and Mary Coulter. 2012. Management. New Jersey: Pearson Prentice Hall. 377

70. Sallis, Edward. 2006. Total Quality Management in Education. Jogjakarta: IRCiSoD. 19

71. Sahib, Muhammad Ichsan. 2012. Pengaruh Kualitas Pelayanan terhadap Kepuasan Konsumen pada MATSC PT (Persero) Angkasa Pura I Makassar. Skripsi. Makasar: Universitas Hasanuddin.

72. Santoso, Singgih. 2010. Statistik Parametrik: Konsep and Aplikasi dengan SPSS. Jakarta: PT. Elex Media Komputindo. 200-206 
73. Sedarmayanti and Syarifudin Hidayat. 2002. Metode Penelitian. Bandung: Mandar Maju.74

74. Singarimbun, Masri and Sofyan Effendi. 1995. Metode Penelitian Survei, Jakarta: LP3ES.

75. Sheikh, Sahal M., and Mehmet Basti. 2015. Customer Satisfaction in Business to Consumer (B2C) E-commerce: A Comparative Study of Turkey and Pakistan. Eurasian Journal of Business and Economics. 8(16), 73-100

76. Shonk, David J., et.al. 2017. Measuring Event Quality, Satisfaction, and Intent to Return at an International Sport Event: The ICF Canoe Slalom World Championships. Journal of Global Sport Management 2:2, 79-95.

77. Sugiyono. 2002. Statistik Untuk Penelitian, Bandung; Alfabeta. 55

78. Sugiyono, Agus. 2001. Ulasan Kritis Artikel: A Child's Guide to Rational Expectations. Yogyakarta: Fakultas Ekonomi Universitas Gadjah Mada. 2-4

79. Susilo, Djoko. 2009. "Implementasi Program "Quick Win” Pada Fungsi Lalu Lintas", edisi April, Majalah Jagratara.

80. Tjiptono, Fandy and Gregorius Chandra. 2011. Service, Quality \& Satisfaction. Yogyakarta: Penerbit ANDI. 51

81. Torres, E. and Kline, S. (2013). From Customer Satisfaction To Customer Delight. International Journal of Contemporary Hospitality Management, 25(5), pp.642-659

82. Torres, E. 2014. Deconstructing Service Quality and Customer Satisfaction: Challenges and Directions for Future Research. Journal of Hospitality Marketing \& Management, Volume 23.

83. Transportation Research Board. 1999. A Handbook for Measuring Customer Satisfaction and Service Quality. Washington, D.C. National Academy Press. 18

84. Umar, Husein. 2002. Metode Riset Bisnis, Jakarta: Gramedia

85. Usman, Husaini., and Purnama Setiady Akbar. 2009. Metodologi Penelitian Sosial. Jakarta: PT. Bumi Aksara. 52-54

86. Wahyuningsih, Anis. 2002. Analisa Tingkat Kepuasan Konsumen Berdasarkan Kualitas Pelayanan Pada Rumah Sakit Umum Kabupaten Karanganyar, Skripsi. Surakarta: Fakultas Ekonomi Program Studi Manajemen UMS.

87. Walgito, Bimo. 2003. Psikologi Sosial: Suatu Pengantar, Yogyakarta: ANDI. 35

88. Walsh, Gianfranco., et.al. 2015. Service Employees' Willingness To Report Complaints Scale: Cross-Country Application And Replication. Journal of Business Research 68:3, 500-506.

89. Widarjono, Agus. 2010. Analisis Statistika Multivariat Terapan. Yogyakarta: UPP STIM YKP. 75

90. Yogi S \& M. Ikhsan. 2006. Standar Pelayanan Publik di Daerah. PKKOD-LAN. 279

91. Yuningsih, Tri. 2004. Dasar-Dasar Pelayanan Instansi Pemerintah Menuju Pelayanan Prima: Suatu Telaah Teoritis. Dialogue. JIAKP, Vol.1, No.1. 120-125

92. Zeithmal, Valerie A., A. Parasuraman, and Leonard L. Berry. 1990. Delivering Quality Service: Balancing Customer Perceptions and Expectations. New York: The Free Press. $19-21$ 